\title{
Competences for Education for Sustainable Development in Teacher Education
}

Franz RAUCH ${ }^{* 1}$ AND REgINA STEINER ${ }^{2}$

$\approx$ Competences are intensively discussed in the context of cross-curricular themes, such as Sustainable Development and Education for Sustainable Development (ESD), especially in light of the United Nations Decade for ESD (2004-2015). Recent literature on ESD lists a number of competences for ESD in various fields with the exception of teacher education. A competence model for ESD for educators was generated in the Austrian research project KOM-BiNE (Competences for ESD in Teacher Education) as part of a large-scale EU project. The KOM-BiNE competence model consists of areas of competences within fields of action. The constituent elements of the competence model are described in detail and are illustrated with examples.

Keywords: Education for sustainable development, Competency model, Teacher education

$1 \quad{ }^{\star}$ Corresponding author: Institute of Instructional and School Development, Alpen-AdriaUniversity Klagenfurt, Sterneckstrasse 15, 9010 Klagenfurt, Austria franz.rauch@aau.at

2 University of Teacher Education of Upper Austria, Kaplanhofstraße 40, 4020 Linz, Austria 


\section{Kompetence za poučevanje za trajnostni razvoj na področju izobraževanja učiteljev}

Franz RAUCH* IN Regina STEINER

$\propto$ V zadnjem času - še posebej v okviru desetletja Združenih narodov za Izobraževanje za trajnostni razvoj (2004-2015) - se veliko govori o kompetencah v povezavi z medpredmetnimi vsebinami, kot sta trajnostni razvoj in izobraževanje za trajnostni razvoj. Pregled novejše literature o izobraževanju za trajnostni razvoj nam pokaže, da obstaja kar nekaj kompetenc za izobraževanje za trajnostni razvoj na različnih področjih, razen na področju izobraževanja učiteljev. V okviru avstrijskega raziskovalnega projekta KOM-BiNE (Kompetence za izobraževanje za trajnostni razvoj na področju izobraževanja učiteljev), ki je bil del širšega projekta Evropske unije, je bil oblikovan model kompetenc, ki naj bi jih imeli učitelji za izobraževanje za trajnostni razvoj. Model KOM-BiNE sestavljajo kompetence za različna področja znotraj vzgojno-izobraževalnih dejavnosti. Podrobno so predstavljeni sestavni elementi tega modela, ki so prikazani tudi s konkretnimi primeri.

Ključne besede: izobraževanje za trajnostni razvoj, model kompetenc, izobraževanje učiteljev 


\section{Introduction}

Several policy statements and research papers on education for sustainable development (ESD) have been published since the 1992 UN Conference on Environment and Development in Rio de Janeiro, and notably since the followup summit in Johannesburg, where education for sustainable development was a central theme. The proclamation of the United Nations Decade of Education for Sustainable Development for the period of 2005-2014 reinforced this trend. Various efforts have been made to develop alliances among stakeholders in global learning, citizenship education, intercultural learning, health education, peace education, etc, which can make a contribution to education for sustainable development. Surprisingly, there is broad concurrence in all these educational trends as to which competencies are required to tackle the current problems of humankind and the earth.

Several compilations of the skills needed to enable and promote sustainable development already exist (Nagel \& Affolder, 2004; Tilbury \& Wortmann, 2004). However, little has been published thus far on the skills that ESD teachers need, both in the formal and the informal sectors of education. The project on competencies for education for sustainable development (KOM-BiNE) addressed this specific issue.

The KOM-BiNE competency model provides a framework of reference and reflection for planning, implementing and reflecting on ESD activities. Moreover, it is intended to stimulate reflection or discussion on competencies in ESD, its further development possibly being part of that process (Rauch, Steiner, \& Streissler, 2008).

\section{Sustainable Development}

»Humanity stands at a defining moment in history. We are confronted with a perpetuation of disparities between and within nations, a worsening of poverty, hunger, ill health and illiteracy, and the continuing deterioration of the ecosystems on which we depend for our well-being (United Nations Conference, 1992, p. 1).

So states the preamble to Agenda 21, the programme of action for the 21st century that was adopted by the World Summit for Environment and Development in Rio in 1992 by virtually all countries of the world.

Sustainable development is to solve the above problems:

»However, integration of environment and development concerns and 
greater attention to them will lead to the fulfilment of basic needs, improved living standards for all, better protected and managed ecosystems and a safer, more prosperous future. No nation can achieve this on its own; but together we can - in a global partnership for sustainable development « (United Nations Conference, 1992, p. 1).

As early as 1987, the World Commission for Environment and Development (WCEF) defined the concept of "sustainable development « (in the Brundtland Report Our Common Future) as a »development that meets the needs of the present without compromising the ability of future generations to meet their own needs « (Hauff, 1987, p. 43). This also implies that environmental conservation is no longer seen as a preferred means of preserving resources for future generations, a tenet held predominantly and unilaterally by the Western world, since:

"Sustainable development requires us to acknowledge the interdependent relations between people and the natural environment. This interdependence means that no single social, economic, political or environmental objective be pursued to the detriment of others. The environment cannot be protected in a way that leaves half of humanity in poverty. Likewise, there can be no long-term development on this depleted planet« (UNESCO, 2002, p. 8).

A fair and equitable distribution of capital and natural resources, and of living and development opportunities, among all people in the world was the ambitious objective of the global community.

Sustainable development, however, is neither a general guideline, nor a clearly defined objective. The concept tells us little about how justice should be achieved. "The concept of sustainable development - as this document suggests - is not a simple one, and there is no road map to prescribe how we should proceed « (UNESCO, 1997, Preface). The way to reach that aim needs to be renegotiated for any given situation. All relevant stakeholders should be included.

A sustainable economy and society can only be the outcome of a social process of searching, learning and design (Rauch, 2004). The ability to constructively contribute different conceptions and interests will be of crucial relevance (Minsch, 2000). Sustainable development can serve as a guiding principle and framework for reflection on this process of such a search.

Homann (1996) called this function a »regulative idea«, a term he borrowed from Kant (1787/1956). According to Homan, regulative ideas serve as heuristics for reflection. They:

[...] steer the searching, research and learning processes in a given direction and direct it to a given focus; in this manner they keep us from 
poking about in a fog, incoherently and haphazardly. One needs at least an intuitive idea of what one is looking for. Without such pre-concepts, one cannot even formulate a reasonable question or identify a problem [...]. Heuristics may help determine the agenda, keep it under a common focus, attract attention to interdependencies in this field, but they cannot determine specific recommendations and proposals. (Homann, 1996, 38f)

The non-descriptiveness of sustainable development as a guiding principle can be perceived as a deficiency; sustainability can be discounted as an empty formula, even a container term (Eblinghaus \& Stickler, 1996). Conversely, it may also be seen as an opportunity, even a precondition, to fulfil its function (Brand, 1997). The different interpretations to which this guiding principle lends itself give it a broad range of points to integrate. The term's lack of precision and its non-descriptiveness can make for a highly creative, diverse, yet dynamic field, which is oriented to a certain direction. In open societies, open notions are likely to resonate; this is precisely what is seen in the current debate on sustainable development. Sustainable development forms a favourable backdrop for reacting to the complex issues that contemporary society is facing in an adequate, manageably complex and not over-simplifying manner (Rauch, 2004).

The concept of sustainable development (SD) should not be limited to an overly pessimistic stock-taking of global problems, but rather should present an optimistic approach, i.e. a realisable vision of a desirable future. Society as a whole should therefore participate in creating such a vision for tomorrow, which takes into account the viewpoints and interests of all social groups and tries to balance them. As a regulative idea (see above), the objective of sustainable development should serve as a guiding principle that spells out the direction of where to go, but not the ways or means of reaching that goal. The aim should be a socially responsible, economically just and ecologically viable development that embraces humanity as a whole and includes opportunities for future generations to thrive (Steiner, 2011). This claim presents novel and ambitious challenges to individuals, as well as to society at large. Here, education is perceived as the master key to achieving a sustainable society: »It is widely agreed that education is the most effective means that society possesses for confronting the challenges of the future [...] « states UNESCO’s policy report Education for a Sustainable Future (1997, paragraph 38). In 2000, the World Education Forum in Dakar noted that education constitutes the true basis for sustainable development (UNESCO, 200o). In late 2002, the United Nations Plenary Assembly thus proclaimed the Decade of Education for Sustainable Development. 


\section{Education for Sustainable Development - A Socio-Political Balancing Act}

Education must be geared to social visions and cannot be detached from society. However, it must be clear about its limited impact. What legitimises education for sustainable development is therefore the regulative idea of sustainable development, not its concretisation (Kyburz-Graber et al., 2000; Rauch, 2004).

Teachers must be aware of the social dilemma in which ESD operates. However, as educators it is precisely their task to encourage and empower the next generation to partake in shaping society. Whenever facts are complex and controversial, whenever social and economic interests conflict, it is inadequate to "settle the facts without strengthening the persons", Nagel and Affolter (2004) stated, borrowing a quote from Hartmut von Hentig. It is only individuals with a sufficiently developed strength of self who can act self-confidently on the basis of their own reflection, especially when issues are contradictory and complex (Heinrich et al., 2007).

ESD gives social concerns the appearance of social policy visions, an idea of a better world to which it can be directed. »Education is about hope and therefore about strong and existential feelings of future«, Oelkers (1990, p. 1) maintained. In this context, Künzli David (2007) mentions three requirements that pedagogical visions for Education for Sustainable Development must meet:

- While recognising social problems, a pedagogical vision must inspire optimism. With an orientation to the notion of sustainable development, it is possible to convey complex facts to pupils while giving them the feeling that the problems at hand can be tackled. Sustainable development does not deny problems, but presents them as fundamentally manageable. It can therefore generate and strengthen young people's optimism about the future.

- Reality is complex and pluralistic; therefore, a pedagogical vision must not propose a one-sided view. Here, the regulative idea concept is an appropriate reference frame for sustainable development. What is sustainable depends on the conditions imposed by where and when stakeholders find themselves, and requires a process of negotiation.

- Shifting social visions to the pedagogical level must not be the only measure by which to implement them. Education is only one measure that must go hand-in-hand with political and social transformations. Education for sustainable development does not aim at changing people's lifestyles, but at »empowering and encouraging them to participate in designing sustainable development and to critically reflect on their own action in this area." (Künzli David, 2007, p. 30) 
The recommendations for the Austrian educational strategy for sustainable development (Heinrich et al., 2007) explicitly outline and call for these structural preconditions. Jürg Minsch (2004) argued that progress can only be expected if society as a whole is seen as a system of innovation. Merely transforming individual skills does not suffice; what is needed is an appropriate scope for action and structures that allow individuals and social groups to commit themselves to a sustainable lifestyle.

The challenges presented by this concept require a reform of the general framework and of the organisational forms governing the educational system, but also innovation in teacher education that empowers teachers to take effective action within the system of education. However, there is no common definition of the competencies that ESD teachers should have.

\section{The KOM-BiNE Competency Model}

The above challenge prompted a large-scale EU project (CSCT) involving 15 teacher training institutions in eight European countries, in which Austria actively participated. In the course of this project, a competency model was elaborated for stakeholders in education for sustainable development (Sleurs, 2007), as well as an Austrian research project that was financed by the Austrian Federal Ministry of Education, the Arts and Culture for the further development of this model. This model of the competencies the ESD teachers should have acquired in training (KOM-BiNE) is discussed in the following.

The concept was differentiated and concretised (Rauch, Streissler, \& Steiner, 2008, 2008a; Steiner, 2011) based on the interpretation of competence used by the OECD in the DeSeCo (definition and selection of competencies) project (Rychen \& Salganik, 2003). In a dense phrase, Weinert defined competencies as:

[The] cognitive abilities and skills which individuals have or can acquire to solve given problems, as well as the related motivational, volitional and social willingness and skills to apply such solution in variable context successfully and responsibly. (Weinert, 2001a, 27f)

In order to tackle a complex problem one must not only understand the facts, which in turn presupposes know-how and skills, but also mobilise motivation, feelings and values (Rychen \& Salganik, 2003). Findings of neurological research show that thinking and feeling are inseparably linked (Gonczi, 2003). Reason exists in and for the entire being, not outside of it. To be successful, educational programmes must therefore also embrace the area of affection (de Haan, 2008). 
Moreover, competencies do not exist independently of action and context, but are applied by acting in given contexts. Here is where the link and interaction between individuals and society becomes apparent. When formulating ESD competencies, attention should be paid not only to individual skills and abilities, but also to the setting and context (for teachers, e.g. classroom teaching, school community, society).

Weinert (2001b) further pointed out that the skills referred to in recent decades are team or group competencies, i.e. the interplay of individual competencies that enable a group to solve problems jointly. Especially in the context of ESD, cooperation and joint problem solving are of fundamental importance. Having to develop all ESD competencies on one's own is an endeavour that would certainly overtax any individual. As cooperation between all players in the area of ESD is paramount, the KOM-BiNE concept is not based on individuals, but on a group whose members pool their competencies for ESD in specific projects or issues and act as a team. Only with cooperation and targeted competency development within a team is it possible to fulfil the complex task presented by ESD.

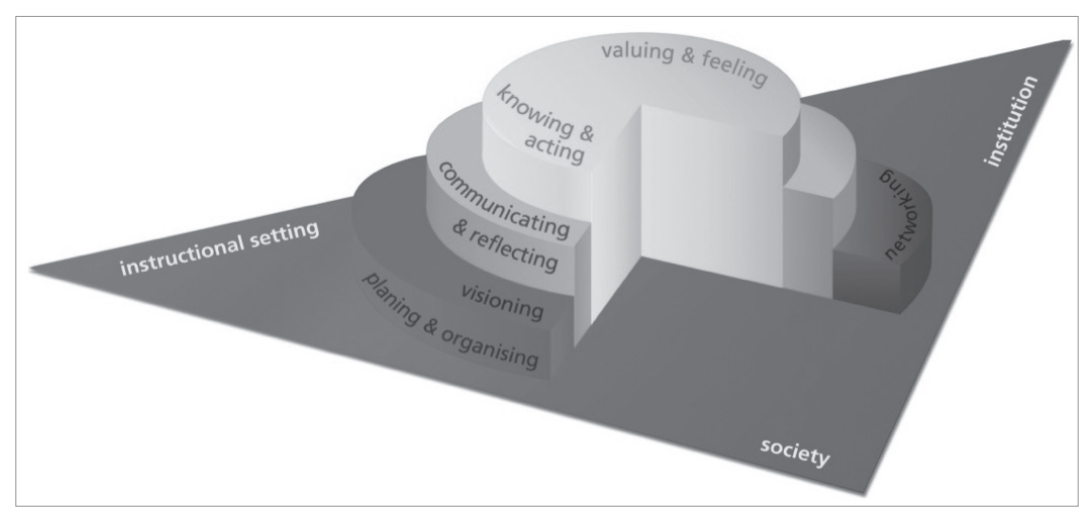

Figure 1: The KOM-BiNE model (Rauch, Streissler, \& Steiner, 2008, p. 15)

\section{Fields of action}

Importantly, ESD competencies are competencies for teachers who are presumed to use their competencies in three different social settings. Three different fields of action exist:

- $\quad$ instruction, i.e. classroom teaching or extramural activities;

- $\quad$ participation in the design of one's own educational institution;

- reaching out to society, to the institution's closer and wider environment.

In the instructional setting, teachers need competencies to create a climate 
that is conducive to learning, to arrange for an appropriate learning environment, to connect with the individual background and abilities of the learners, to select and use appropriate methods, and to create opportunities for active involvement. Within the institutional and societal settings, teachers must look for cooperation partners within and outside of their own institutions. While these are skills teachers generally need, they are paramount in the complex ESD setting, which requires a high degree of readiness to cooperate, to solve conflicts and to work in teams. Outside one's own institutions, the ability to establish contact and cooperation with other educational institutions and to arrange learning opportunities for the learners (e.g. through participation in local Agenda 21 processes) is needed. While such competencies are of course desirable in other educational settings as well, they are indispensable for ESD for the reasons stated.

The constituent elements of the competency model are described in detail in the following and, for a better understanding, illustrated by examples from ESD courses.

The core area of the model consists of more individual aspects, which are divided into four fields: »knowing and acting « (subject-matter knowledge, e.g. specific knowledge of ESD, and methodological know-how - ESD didactics and methodologies), »valuing« and »feeling«. These areas are closely interrelated.

\section{"Knowing"}

This revolves around:

- acquiring general knowledge of the contents of sustainable development and of education for sustainable development;

- connecting contents from the different disciplines and from social and cultural contexts, and being able to understand their interactions and interdependencies;

- becoming aware that knowledge is culture and value driven;

- $\quad$ tackling the uncertainty, preliminarity and contradictions of such knowledge;

- critically challenging knowledge and developing it further in a joint, proactive approach.

By way of illustration, the authors will report on a case study from a course held at the University of Klagenfurt on »Innovation in Teacher Education - Education for Sustainable Development (BINE)« for teacher-training institutions:

Instead of a mere theoretical discussion of knowledge, the course programme provided for project-oriented and independent research on sustainable development. The participants in the BINE study course elaborated their own concept of sustainability, by studying, presenting and evaluating 
concrete sustainability initiatives on site. They shared findings and matched them against published literature. In this way, the participating teachers were able to experience hands-on research-driven learning in their own work. In the project, it was essential to engage in a meta-reflection of the learning experiences for one's own teaching (Steiner, 2011).

\section{"Acting"}

In this area, the players know a repertoire of methods and strategies for how to apply the knowledge and are able to further develop these methods themselves. The aim is to foster the following skills among learners:

- $\quad$ determining and developing values;

- $\quad$ critical thinking and the ability to reflect;

- handling complexity;

- $\quad$ developing future perspectives;

- conflict-solving, communication and teamwork;

- $\quad$ problem-solving;

- $\quad$ participation and responsibility; as well as

- $\quad$ independent and self-reliant action.

The teachers focus on the action-orientation and contextualisation of the contents. In the formal system of education, they moreover know and use methods of supportive performance evaluation.

Awareness that the acquisition of competencies depends on domains is crucial. Knowledge and skills are acquired and applied in concrete action domains.

In a research project conducted at the University of Berne (BINEU - Education for Sustainable Development in the Lower Cycle) (Künzli David, 2007), the participating teachers had to implement the theoretical concept of ESD in practice and determine, relying on their knowledge and experience as secondary school teachers, whether pupils in the lower cycle of secondary schooling were able to understand the concept of ESD. They discussed which examples of ESD were useful in teaching, and jointly developed potential contexts and methods. In small groups, they then worked on detailed plans for their classes and were continuously supported by the project leaders. In this manner, they were able to develop ESD methods with scientific guidance, expand the methodological repertoire, share experiences, and learn from one another.

\section{"Feeling"}

In the area of feeling, the players try to empathise by e.g. listening, and putting themselves in the place of others (change of perspective). Their attitude is optimistic; 
they are convinced that sustainable development is viable and that, together, they can make a contribution toward that end. They keep their enthusiasm for ESD alive and try to inspire others to do the same. Instead of promoting fears and frustration by doomsday rhetoric, they encourage learners in their commitment (empowerment).

By its nature, ESD is an optimistic, future-oriented concept built on the idea that a sustainable world is possible and that individuals can make a contribution.

The 'Global Learning' study course run by Südwind Österreich identified approaches of how to deal with devastating and depressing contents. It offers methods of how to handle such contents emotionally, by e.g. drama acting, painting etc. At the same time, it became clear that learners can only engage in such a form of learning if the teachers manage to create an appreciative atmosphere at school (Steiner, 2011).

\section{"Valuing"}

ESD is not a random, but a fundamentally normative concept. Some models exist that set out quality criteria for ESD (Breiting, Mayer, \& Mogensen, 2005). »Values« has a multi-layered dimension. Firstly, it relates to values that the players themselves stand and argue for. Secondly, it relates to the educational objectives that are to be promoted or altered, such as a respectful attitude vis-à-vis others, overcoming black-and-white mentalities in the context of sustainable development, etc. Thirdly, it is about values that are lived and which manifest themselves as (unconscious or consciously reflected) attitudes and beliefs, e.g. regarding heterogeneity and diversity as an opportunity and using it as such in the teaching setting. It is also about how values per se are addressed in instruction, such as in debates on values.

Attention is drawn to methods of promoting secological judgment competencies", as postulated by Susanne Bögeholz and Jan Barkmann (2003) and others. By this, they understand »the ability to apply factual ecological knowledge systematically to environmentally relevant values to be able to reach a judgment on which decisions are based." (Bögeholz \& Barkmann, 2003, p. 27) or, even beyond that, the "competence to make an ecological judgment [...] the ability to reflect on one's own ethic values as well as a communication repertoire in the search for consensus and fair compromise« (ibid.). Teachers themselves should have those competencies; in the competency model, knowing methods to promote and apply these competencies would fall under the heading of »acting « (see above).

The experience of teachers in the Swiss BINEU project may serve as example: Teachers found a consistently open and appreciative attitude towards pupils to be one of the quintessential and at the same time most difficult requirements, explaining:

It is not about training children to adopt a behaviour which has been recognized as »correct «, but about supporting them in taking decisions based on their own judgment. »In the past, I wanted to convey to the children 
something along the lines of: »What is good? What is the right way of doing things? »Black and white somehow. Now, with the concept of sustainable development, I have abandoned this altogether. (Steiner, 2011, p. 237)

As the focus was on being empowered to negotiate and to decide, and not to modify behaviours, the teachers had to tolerate and accept that pupils sometimes arrived at conclusions that differed from what they had planned. In such a situation, instruction no longer aims at pushing pupils towards making a better world, but empowers them to take independently justified decisions based on differentiated knowledge and reflected values.

\section{»Communicating « and »Reflecting"}

The middle layer of the competency model consists of "reflecting" and "communicating «, and refers to both outwardly directed activities (the outer layer, shown in purple, and to more individual areas (the innermost layer), thereby creating a link between the two.

Communicating is an ability without which all other areas are inconceivable. While communication is a sine qua non for planning, organising, and networking, it is not a matter of course for the more individual areas. Especially in ESD, however, communication is indispensable for:

- values - an appreciative dialogue that respects the opinions of others and takes them seriously,

- feeling - the ability to address highly personal issues, which tend to be given short shrift or completely left aside in teaching, and

- $\quad$ knowing and acting - e.g. sharing one's own experiences, personal knowledge and skills, not wanting to keep them to oneself, making them useful for others according to the »strength concept « (McKeown, 2002).

Reflection is important as a means to critically deal with oneself, one's own know-how and skills, values and feelings. Such reflection is equally important with regard to action taken, and is therefore related to the top layer of the KOM-BiNE model (knowledge and skills, values, feeling), as well as to the bottom level (developing visions, planning, organising, networking).

The teachers participating in the BINEU research project became aware of how crucial personal reflection and the further development of teaching is, because »education for sustainable development is a change of paradigm, not just a continuous further development, which makes the matter more difficult for many of those involved « (Steiner, 2011, p. 244). For the introduction of ESD, in-service teacher education, internal training events, team formation and support from networks are 
often required as gate openers. For teachers, this may mean that reflection becomes second nature to them, using tools such as a learning diary or action research.

As another finding, teachers discovered that they had to use the allocated teaching time differently; they needed sufficient time to develop the relevant contexts, but also for allowing pupils to reflect on what they had learned, the insights they had gained, and whether this form of learning was useful for them.

\section{"Visioning", "Planning « and »Organising "}

Sustainable development is an optimistic concept. It is not only about identifying and reacting to the problems of the present, but also about developing visions for the future. How do we want to live sustainably? Or with regard to teaching: What should learning look like in the future? Where are we heading with our teaching, our school in general? What are our goals?

This three-step approach consists of (1) setting objectives, (2) reflecting on what is possible in a given situation, and (3) translating these ideas into reality.

\section{"Networking«}

Building and maintaining networks within organisations and externally with other persons and institutions is vital for the ESD competences of teachers: With ESD being such an extremely complex field of action, in which diverging domains such as the economy, the environment, society and politics must be interlinked, and for which broad methodological knowledge is required, it is more or less impossible for teachers to act as independent individuals. They must set up contacts with others, engage in exchange, work in groups and teams, and cooperate with others and with their institutions. Successful cooperation within their institution as well as with external persons and institutions thrives on team work, communication skills, conflict management, tolerance, respect of heterogeneity and diversity, etc.

As one requisite competence, ESD teachers must be able to organise and moderate cooperation with non-formal educational institutions, in order to arrange for learning opportunities for pupils in and with extramural institutions. Pupils want to be taken seriously, act constructively in their own environment, and be able to leave an imprint (Posch, 1997). From a pedagogical perspective, however, the over-arching criterion is not only the implementation of successful activities or visible change in the surrounding world, but selecting opportunities for learning based on their inherent potential for learning (Breiting, Mayer, \& Mogensen, 2005; Künzli-David, 2007). For this, teachers need communication as well as planning and organisational skills, so that they can create favourable teaching-learning settings at their own institutions as well as an appropriate framework for cooperation in the social environment. 


\section{Conclusion and Outlook}

Based on the notion of sustainable development as a regulative idea outlined above, the link between sustainable development and education can be summarised as follows: sustainable development is part and parcel of a general educational task, aimed at empowering the young generation to design their conditions of life on a more humane scale. It is based on an educational notion which focuses on the self-development and self- determination of human-beings as they interact with, and reflect on, the world, with others, and with themselves. Education relates to the ability to contribute to the design of society in a reflected and responsible manner in terms of sustainable future development.

In the context of sustainable development, learning is equivalent to addressing issues of how to sustainably shape the future in concrete fields of action. This includes observation, analysis, assessment and design of a given context in creative and cooperative processes. »Reflected design competence«- not »blind action« or unreflective action patterns - is the primary goal of learning, which could be rooted in ecological, social and political dimensions. »Communities of learners" (teachers, pupils, students, researchers) jointly explore interrelations and options for acting, they intervene and reflect on action taken. What is addressed and called for specifically are a critical assessment of knowledge in the light of the present-day information overload, the development of self-worth, self-determination and self-reliance, as well as social competencies such as the ability to participate (Rauch, 2008).

The UN Decade of Education for Sustainable Development is an opportunity to promote existing initiatives and discourse on education and sustainable development in its varied manifestations such as environmental education, citizenship education, global learning, peace education, health education, consumer education and many others. It can offer a »forum « for exchange, reflection and - ideally - cooperation on the common path towards a sustainable future. A discourse in which all players participate on an equal footing requires common objectives that transcend individual interests. The all-important question is how the design of a sustainable future can be interlinked with education. Intervention and critical reflection (learning) are the essential cornerstones.

\section{References}

Bögeholz, S., \& Barkmann, J. (2003). Ökologische Bewertungskompetenz für reale

Entscheidungssituationen: Gestalten bei faktischer und ethischer Kompetenz. DGU Nachrichten 27/28,

Jahresheft 2003, 25-34.

Brand, K. W. (Ed.) (1997). Nachhaltige Entwicklung. Eine Herausforderung für die Soziologie. Opladen:

Leske+Budrich. 
Breiting, S., Mayer, M., \& Mogensen, F. (2005). Quality criteria for ESD schools. Guidelines to enhance the quality of Education for Sustainable Development. ENSI - SEED Network. Wien: BMBWK.

Gonczi, A. (2003). Teaching and learning of the key competencies. In D. S. Rychen, L. H. Salganik, \& M. E. McLaughlin (Eds.), Contributions to the second DeSeCo symposium (pp. 117-131). Neuchatel: Swiss Federal Statistical Office.

De Haan, G. (2008). Gestaltungskompetenz als Kompetenzkonzept für Bildung für nachhaltige Entwicklung. In I. Bormann \& G. de Haan (Eds.), Kompetenzen der Bildung für nachhaltige Entwicklung (pp. 23-44). Wiesbaden: VS Verlag.

Eblinghaus, H., \& Stickler, A. (1998). Nachhaltigkeit und Macht. Zur Kritik von Sustainable Development. Frankfurt: Verlag für Interkulturelle Kommunikation.

Hauff, V. (Ed.) (1987). Unsere gemeinsame Zukunft. Der Brundtland-Bericht der Weltkommission für Umwelt und Entwicklung. Greven: Eggenkamp-Verlag.

Heinrich, M., Minsch, J., Rauch, F., Schmidt, E., \& Vielhaber, C. (2007). Bildung und Nachhaltige Entwicklung eine lernende Strategie für Österreich. Empfehlungen zu Reformen im Kontext der UNODekade. Bildung für Nachhaltige Entwicklung (2005-2014). Münster: Monsenstein \& Vannerdat. Homann, K. (1996). Sustainability: Politikvorgabe oder regulative Idee? In L. Gerken (Ed.),

Ordnungspolitische Grundfragen einer Politik der Nachhaltigkeit (pp. 33-46). Baden-Baden: Nomos Verlagsgesellschaft.

Kant, I. (1787/1956). Kritik der reinen Vernunft. Hamburg: Felix Meiner Verlag.

Konferenz der Vereinten Nationen für Umwelt und Entwicklung. (1992). Rio de Janeiro. Retrieved from http://www.un.org/depts/german/conf/agenda21/agenda_21.pdf

Künzli-David, C. (2007). Zukunft mitgestalten. Bildung für eine Nachhaltige Entwicklung - Didaktisches Konzept und Umsetzung in der Grundschule. Bern: Haupt.

McKeown, R. (2002). Education for Sustainable Development Toolkit. Retrieved from www.esdtoolkit.org Minsch, J. (2000). Nachhaltige Entwicklung I. Grundlagen nachhaltigen Wirtschaftens. MS. Wien: BOKU. Nagel, U., \& Affolter, C. (2004). Umweltbildung und Bildung für eine Nachhaltige Entwicklung - Von der Wissensvermittlung zur Kompetenzförderung. Beiträge zur Lehrerbildung, 22(1), 95-105. Oelkers, J. (1990). Utopie und Wirklichkeit. Ein Essay über Pädagogik und Erziehungswissenschaft. Zeitschrift für Pädagogik, (1), 1-13.

Posch, P. (1997). Soziale Veränderungen - was bedeuten sie für die Schule? Zusammenfassender Bericht auf der Grundlage von Expertenworkshops im Auftrag des Bundesministeriums für Unterricht und kulturelle Angelegenheiten. Klagenfurt: Universität Klagenfurt.

Rauch, F. (2004). Nachhaltige Entwicklung und Bildung. In R. Mikula (Ed.), Bildung im Diskurs (pp. 35-49). München, Wien: Profil.

Rauch, F. (2008). Bildung für Nachhaltige Entwicklung als eine lernende gesellschaftspolitische Strategie. In G. Gruber \& K. Stainer-Hämmerle (Eds.), Demokratie lernen heute (pp. 173-188). Wien: Böhlau. Rauch, F., Streissler, A., \& Steiner, R. (2008). Kompetenzen für Bildung für Nachhaltige Entwicklung (KOM-BiNE). Konzepte und Anregungen für die Praxis. Wien: BMUKK.

Rauch, F., Steiner, R., \& Streissler, A. (2008a). Kompetenzen für Bildung für nachhaltige Entwicklung 
von Lehrpersonen. In I. Bormann \& G. de Haan (Eds.), Kompetenzen der Bildung für nachhaltige Entwicklung (pp. 141-158). Wiesbaden: VS Verlag.

Rychen, D. S., \& Salganik, L. H. (Eds.) (2003). Key competences for a successful life and a well-functioning society. Cambridge (State of Washingtion), Göttingen: Hogrefe \& Huber.

Sleurs, W. (2007). Competencies for ESD (Education for Sustainable Development) teachers. A framework to integrate ESD in the curriculum of teacher training institutes. Report.

Steiner, R. (2011). Kompetenzorientierte Lehrer/innenbildung für Bildung für Nachhaltige Entwicklung. Münster: Monsenstein \& Vannerdat.

UNESCO (Ed.) (1997). Educating for a Sustainable future. A transdisciplinary vision for concerted action. EPD-97/CONF.401/CLD.1. Retrieved from http://www.unesco.org/education/tlsf/mods/theme_a/ popups/modo1to5so1.html\#pre

UNESCO (2000). The Dakar framework for action. Education for All. Meeting our collective commitments. Adopted by the World Education FORUM in Dakar, Senegal, 26 - 28. April 200o. Retrieved from http:// unesdoc.unesco.org/images/oo12/o01211/121147e.pdf

UNESCO (2002). Education for Sustainable Development. From Rio to Johannesburg: Lessons learnt from a decade of commitment. Report presented at the Johannesburg world summit for Sustainable Development. Paris: UNESCO. Retrieved from http://unesdoc.unesco.org/images/oo12/o01271/12710oe.pdf

Weinert, F. E. (2001a). Vergleichende Leistungsmessung in Schulen - eine umstrittene

Selbstverständlichkeit. In F. E. Weinert (Eds.), Leistungsmessungen in Schulen (pp. 17-31). Weinheim, Basel: Beltz.

Weinert, F. E. (2001b). Concept of competence: A conceptual clarification. In D. S. Rychen \& L. H. Salganik (Eds.), Defining and selecting key competencies (pp. 45-66). Cambridge (State of Washington), Göttingen: Hogrefe \& Huber.

\section{Biographical note}

Franz RAUCH, Prof. Dr., was a science teacher for several years and is currently head of the Institute of Instructional and School Development (IUS) at the Alpen-Adria University Klagenfurt (Austria). His areas of research and teaching are environmental education, education for sustainable development, science education, networking of teachers, school development, continuing education for teachers, and action research.

Regina STEIner, Dr., primary school teacher, teacher of biology and environmental education for higher education, $\mathrm{PhD}$ in Pedagogic at the Alpen-Adria-University Klagenfurt, head of FORUM Environmental Education in Salzburg since 1987, lecturer at the University of Teacher Education of Upper Austria and the Pedagogical University for Agrarian- and Environmental Education in Vienna. 